\title{
AN ANALYSIS OF THE ACCOUNTING PRINCIPLES APPLIED BY THE EUROPEAN FARM ACCOUNTANCY DATA NETWORK
}

Slof, E.J. / Argilés, J.M.

Pompeu Fabra University

February 1998; revised October 1998

We acknowledge the help of the FADN Division of the D.G. VI for Agriculture of the European Commission. 


\section{INTRODUCTION}

In spite of its relative importance in the economy of many countries and its growing interrelationships with other sectors, agriculture has traditionally not received much attention from accounting researchers, practitioners and standard setters. Consequently, farm financial statements typically do not respond very well to the particular characteristics of agricultural business and the information needs of farmers and their stakeholders. Together with other reasons, like a generally lower level of managerial sophistication, this has led to a situation in which farmers are more reluctant to prepare accounting reports and use this kind of information to a lesser extent than the agents in other economic sectors (Poppe, 1991; Poppe and Breembroek, 1992). Several authors, like Kroll (1987), André (1987), or Sabaté and Enciso (1997), have pointed out that when farmers use accounts, it is mainly to comply with tax and subsidy requirements.

On the other hand, it is generally believed that accounting can improve farm management and lead to better farm performance (see for example, Luening, 1989; Allen, 1994). Furthermore, agricultural lenders often claim more and better accounting information (Bronstien, 1995; Crane and Leatham, 1995), which is consistent with empirical evidence that accounting data makes a significant contribution to explaining and predicting farm failure (Argilés, 1998). Given the government interference in many agricultural markets in many countries, also policy makers have a need for accounting information.

In Europe, the Common Agricultural Policy (CAP) has been one of the cornerstones of the economic and political integration process, and to date the European Union's Directorate for agriculture still is the one with by far the largest budget. It is logical therefore that the Commission of the European Community (CEC) has a need for information on the financial performance and condition of farms to support decision making for and control of the CAP. This information need is not limited to aggregate macro-economic data, but also extends to the level of individual farms, and the European Commission had to make an effort to obtain standardized information. For this reason the Council of the European Commission created the Farm Accountancy Data Network (FADN $)^{1}$. This network collects accounting information at the level of individual farms, and gathers every year data from a rotating sample of 60.000 professional farms across all member states.

Besides other types of information which are expressed in physical measures only, the data collected concerns assets, liabilities, revenues and expenses of the farms in the sample, and is summarized in reports similar to balance sheets and income statements. 
To the accountant it seems that FADN attempts to obtain something like a "true and fair view" of the financial performance and condition of the farms, although this is not stated explicitly anywhere. Since many farms do not provide reliable financial statements and when they do these statements are not directly comparable between countries, FADN had to develop and put in practice detailed guidelines and resolve both specific and general farm accounting issues by itself. In this way, FADN has developed to a similar level of complexity and comprehensiveness comparable to the national accounting plans of some countries.

While the sampling, data collection and data processing procedures of FADN are very elaborate and well documented, the information content of its reports is in some respects questionable. Particularly, from the perspective of the accounting discipline, there are several points of concern. In the first place, FADN data is not obtained through bookkeeping procedures but through a questionnaire. Second, and more importantly, the definitions used in the FADN questionnaire and its presentation of the financial statements are often at odd with basic Generally Accepted Accounting Principles (GAAP).

This paper focuses on this second concern. Particularly, the methodology employed by FADN is contrasted with the accounting principles found in the IVth Directive of the European Union (EU) and the recent Draft Statement of Principles on Agriculture (DSOPA) issued by the International Accounting Standards Committee (IASC). The purpose of this analysis it to identify where FADN should change if it is to be made more in accordance with the accepted accounting framework. There are two reasons why this can be useful.

First, GAAP can be understood as a condensation of the expertise of the accounting profession. Incorporating this expertise in FADN should presumably improve the quality of its data and make it a better source of information for policy makers and researchers. Second, as there is currently little guidance in the European Union for the preparation of financial statements for agricultural enterprises, FADN sometimes is fulfilling the role of a standard-setting body (Poppe and Beers, 1996). However, as Dedman (1996) observed, the departure from GAAP may be the most significant block to its acceptance by accountants. Bringing FADN closer to GAAP could make it more effective as a guideline for farm accountants, and may even turn it into the starting point for a European accounting standard on agriculture.

Contrasting FADN with both the DSOPA and the IVth Directive, also reveals some contradictions between the latter two, which is interesting by itself. The conflict between 
the EU and IASC is a complex matter, however, as can be seen from the discussion between Flower $(1997,1998)$ and Cairns (1997), that is beyond the scope of this paper.

The remainder of this paper is organized as follows. Section two provides further background about FADN. Section three analyzes the accounting principles it applies in its reports. Particularly, the valuation of assets, and the recognition and valuation of revenues and expenses are studied, as well as their presentation in the financial statements. Section four, finally, contains the major conclusions.

\section{THE FARM ACCOUNTING DATA NETWORK (FADN)}

The six founding member states of the European Economic Community (EEC) set up the Common Agricultural Policy (CAP) to implement the five objectives that were promulgated in Article 39 of the Treaty of Rome. The desire to monitor the performance of CAP led to a need for information about the situation of the agricultural sector in the member states. Objective information about the performance and income of the different types of farms existing in the EU was required which could not be found in the macroeconomic "Economic accounts for Agriculture" provided by EUROSTAT. Therefore FADN created in 1965, through Regulation (EEC) 79/65 of the Council. At least at that time, FADN was only conceived as a complementary source of statistical information for policy makers and not as a tool to be used by farmers or other stakeholders (CEC, 1991).

Complete documentation of FADN can be found in CEC (1988; 1990). Its basic features can be summarized in the following points:

1) FADN aims to gather accounting data on the performance and income of farms in the EU.

2) FADN data are not obtained at a macro-economic level, but from a random rotating sample of approximately 60.000 individual farms across all member states.

3) The field of observation of FADN is that of "commercial" farms. A minimum European Size Unit is established in each member state to define the commercial farm.

4) The sample is stratified by region, farm size and type of farming. 
5) FADN is a network of networks of accounting offices. The accounting offices differ between the member states. Some are commercial accounting offices that adapt records already kept for tax purposes or investment aids. In other countries the accounts are prepared by research institutes, universities or agricultural trade unions. Many of the accounting offices only keep the records for the purpose of FADN.

The data collected by the accounting offices are transmitted to regional committees and from there to the national liaison offices. The national liaison offices then forward them to the European Commission in Brussels, where FADN's management committee checks the validity of the data and stores them in a database.

6) Depending on the country, either the regional committees or the national offices select the sample for a given stratification. However, the final sample is always conditioned by the participation of the farmers, which is voluntary.

7) FADN data are confidential, which means that they can not be disclosed or used for tax purposes. Therefore, a minimum number of farms is required for each stratum to assure anonymity. FADN never publishes nor otherwise provides information about individual farms.

8) FADN data are collected from a variety of sources, such as bank statements, invoices, etc., through a questionnaire, the "Farm Return". The Farm Return is the core of the FADN data collection procedure and is filled out by the farms with the assistance of the accounting offices. It includes the following 13 sections:
A. General information of the farm.
B. Type of occupation (tenure).
C. Labor input.
D. Number and value of livestock.
E. Livestock purchases and sales.
F. Costs.
G. Land and buildings, deadstock and circulating capital.
H. Debts.
I. Value added tax.
J. Grants and subsidies.
K. Production.
L. Quota.
M. Compensations in arable farming. 


\section{FADN ACCOUNTING METHODOLOGY}

This section analyzes the most notable aspects of the accounting data provided by FADN. Specifically asset valuation, revenue recognition, expenses, and the format of the financial statements are examined here.

\subsection{Assets and their valuation}

The nature of agricultural businesses makes the valuation of their assets on a historical cost base inherently difficult, because many major assets are of a biological nature. The physical state of these assets typically changes over time, i.e. they strengthen, mature, fatten, etc. Furthermore, their quantity does not only depend on buying and selling activities, but is also determined by such processes as procreation, growth, and death.

Consequently, many agricultural assets owned at a certain moment in time are typically substantially different from how they were when acquired, or have never been acquired at all. In this sense they are similar to the produce of manufacturing firms, and product costing techniques could be applied to assign the historical cost of inputs used to outputs obtained. The problems caused by joint-cost situations, however, often far exceed in complexity those already encountered in manufacturing environments. Although some authors (for example, Launay, Beaufrere and Debroise, 1967; Alonso and Serrano, 1991; Pérez, 1993) have made suggestions to overcome some difficulties, costs allocated to individual assets will normally be necessarily very arbitrary (Kroll, 1987).

In spite of the fact that this situation has long been recognized (see for example, Domínguez, 1981), agriculture has not been an exception in the preference of standard setters for historical cost valuation. One notable example in this context is the French "Plan Comptable Général Agricole" of 1986, which strictly adheres to the historic cost principle. Also the American Institute of Certified Public Accountants (1996) and the Canadian Institute of Chartered Accountants (1986) recommended the historical cost principle as the main reference for asset valuation, although these institutes recognize that there may be exceptional situations in which realizable value can be considered.

On the other hand, as the IASC Steering Committee for Agriculture points out ${ }^{2}$, for most agricultural assets relatively efficient markets exist. Market prices are reliable estimates of the fair value of the assets, can be obtained relatively easily, and are more objective than allocations of historic cost. A good case can be made therefore in favor of valuing agricultural assets at current value, like, for example, Lewis and Jones (1980) and Sturguess (1994) do. 
FADN is in line with the latter view, and in most cases uses market prices for the valuation of non-monetary assets. Specifically, livestock is valued at prices prevailing at the beginning and ending of the accounting period. The valuation of land is based on the market price for non-rented land with the same similar characteristics regarding location, quality and use, from which any development costs are deducted. Depreciable fixed assets, such as buildings and machinery, are valued at replacement cost at the beginning and end of the accounting period. Replacement cost is defined here as the price that the farm would pay for a new similar asset. Accordingly, depreciation is calculated on a replacement-cost basis. To the extent that replacement prices are not available or not reliable, FADN updates acquisition cost with specific price indices. Stock of farm output is valued at realizable value at the balance sheet date. It should be pointed out that sales costs are not deducted here. Plantations of permanent crops, finally, are valued at their historical cost.

Although asset valuation based on current value is not a common accounting practice in most European countries, it is not contradictory to the IVth Directive either, which in Article 33 explicitly refers to the possibility of valuing fixed assets and inventories at their replacement value. Furthermore the IVth Directive permits inflation adjustments of historic cost data. Also the Steering Committee of the DSOPA has expressed that fair value is a better basis for the valuation of biological assets, produce and land than historical cost, and further concluded that market price is an indicator of fair value when active markets exists. In the absence of active and efficient markets, the Committee suggests that a choice should be made between different alternatives of current value (i.e., replacement cost, realizable value, or present value). The DSOPA does not refer to the valuation of assets other than agricultural produce, biological assets and agricultural land, however, while FADN uses current values for all non-monetary assets.

In essence therefore, FADN appears to be in accordance with the IVth Directive and the DSOPA. In some important aspects, however, departures can be found. First, there is a conflict with the IVth Directive which excludes land from the assets that may be valued at replacement value. It can be observed, though, that the DSOPA also contradicts the IVth Directive at this point, and that maybe it is the latter that should provide an exception for agriculture. 
Second, questions arise about the treatment of the cumulative changes in current value. FADN includes the holding gains or losses without any further disclosure in owners' equity, while the IVth Directive would require the creation of a revaluation reserve. Like other existing accounting standards (SSAP15, FAS 33, IAS15, IAS16 and IAS29) dealing with accounting and changing prices, the DSOPA explicitly recommends disclosure of this item in the balance sheet. Compliance with the IVth Directive and the DSOPA at this point would require more disclosure from FADN but no change in content.

Finally, the exception made by FADN for plantations of permanent crops seems to be an inconsistency that can easily reversed.

\subsection{Revenue recognition}

As far as revenue recognition is concerned, FADN takes a very unusual approach. Revenues are based on production, valued at end-of-period market prices. This is clearly contrary to traditional GAAP, and the IVth Directive, which, first, normally recognizes revenues when a sales transaction has taken place, and second, values them at actual sales prices.

However, IAS18 refers to production as the moment for income recognition in mining and agriculture under specific conditions: when sales are guaranteed by a government or by a long-term contract, or when a homogeneous market exists that make the risk of sales failure negligible. Also is this approach defended by some authors for farm accounting, like Bublot (1990-1991). The DSOPA, accordingly, makes a proposal which is similar to FADN. Specifically, it suggests to distinguish between three types of increases (decreases) in owners' wealth: (1) sales of agricultural produce valued at sales prices, (2) changes in the carrying amount of agricultural produce and biological assets attributable to changes in the substance of these assets, and (3) changes in the carrying amount of agricultural produce and biological assets attributable to differences in their fair value. The DSOPA suggests to recognize the first two types of changes as revenues and to credit the third type directly to equity. In essence, the only difference between the DSOPA and FADN are the valuation of sales (at sales prices vs. end-of-year market prices), and the treatment of the holding gains (directly credit to equity vs. report as revenues). 
Another concern is the fact that FADN treats subsidies on a cash basis. Given that in the European context subsidies often are a major source of income for farms, this can lead to important differences compared to the accrual-based recognition required by GAAP.

All together, FADN could adapt without major problems to the DSOPA with regard to revenue recognition. Compliance with the IVth Directive appears to be more complicated.

\subsection{Expenses}

FADN distinguishes four broad categories of expenses. These are called specific costs, overheads, depreciation, and external factors. Depending on the type of farm, the specific cost refer to seeds and plants, fertilizers, crop protection, and other crop specific costs, or feed and other livestock specific costs. Overheads include machinery and building costs, energy, contract work, and other direct inputs. The external factors include wages, rent, and interest. Curiously, FADN does not consider the remuneration paid to the farmer and his family, be it in the form of a salary or a dividend, an expense for the farm. The same is true for all social charges whose beneficiaries are the members of the family. Given that the farmer's family in many cases is the major or even only constituent of the workforce, this is of considerable importance. ${ }^{3}$ Equally notable is the fact that expenses not related to the farm activity are not recorded as farm expenses, either.

Both the specific costs and the overheads are determined on an accrual basis, but the external factors are valued on a cash basis. Depreciation is calculated in accordance with the valuation of the corresponding assets, that is normally on replacement value. Consumption by the farm itself of livestock and farm output in general is valued at net realizable value.

The IVth Directive and also IASC standards require all of the entity's expenses to be reported, and all of them on an accrual basis. A considerable effort, but no change in "philosophy" would be required to make FADN compatible with GAAP with regard to this aspect. As pointed out earlier, there is no apparent conflict with GAAP as far as the use of replacement valuations is concerned.

\subsection{Financial statement presentation}

Figure 1 shows the structure of the balance sheets prepared by FADN. The asset side only contains a limited number of items, all of which are strictly related to farming activity. In other words, assets not related to the core activities are not shown. On the liability side of the balance sheet, FADN only distinguishes three items. These are 
owners' equity, long- and medium-term loans, and short-term loans. Although FADN uses the expression "loans", this item includes payables and debts in general. Like the asset side, the liability side only includes items strictly related to farming activity.

Insert Figure 1 approximately here

Furthermore, "change in owners' equity" is included as a separate balance-sheet item. It should not be interpreted as the year's profit or loss, however, because changes may be due to other reasons, like fluctuations in market value of assets, fluctuations in exchange rates, or simply increases or decreases in paid-in capital.

The DSOPA does not explicitly refer to other items than those that are specific of agricultural activities, but must, of course, be read in the context of all other IASC standards, which like the IVth Directive, obviously require a complete and far more detailed presentation of assets, liabilities and owners' equity on the face of the balance sheet. Compliance with GAAP would therefore require from FADN substantially more disclosure.

Figure 2 reproduces the structure of the income statements prepared by FADN. Similar to what was pointed out with respect to the balance sheet, the income statement is not really complete, since revenues and expenses not related to farming activities are not shown in it.

Insert Figure 2 approximately here

Although the vocabulary used is sometimes peculiar, it can be seen that the income statement is basically organized by nature of the revenues and expenses. This type of document, if made comprehensive, could be made to fit into one of the formats provided for income statement in the IVth Directive.

The DSOPA, on the other hand, is rather brief on income statement presentation. It recommends a classification of income and expenses by their nature (no conflict with FADN therefore), and a separate identification of the holding gains due to changes in the fair value of biological assets (which is not provided in FADN yet, but could be obtained easily by splitting out the item "total output"). 


\section{CONCLUSION}

FADN was originally meant to be an instrument for policy makers that made the data about performance and income of the farms from different EU member states comparable. It was not intended to be a way of harmonizing national accounting standards, nor did it ever explicitly aim to follow any type of GAAP. Nevertheless, FADN had to develop and put in practice detailed guidelines for farm accounting. In preparing these guidelines it had to resolve both specific and general farm accounting issues. If FADN is to provide a true and fair view of the financial position and results of farms through accounting information, as it name suggests, the choices made to resolve these issues should be based on sound accounting principles.

On the other hand, in spite that it was not set up for this purpose, FADN fulfills the role of a guideline and point of reference for agricultural accounting in Europe. It appears to be a natural starting point for a European standard, if the EU should decide to issue further legislation of this kind, or recommend it to its member states.

It is warranted therefore to analyze the compatibility of FADN with GAAP. This paper identified several aspects where the accounting choices made by FADN depart from the accounting principles found in the IVth Directive or IASC's DSOP on Agriculture. Specifically, the following departures have been pointed out:

- FADN does not show all assets, liabilities, and owner's equity on the balance sheet; many of the items shown are not disclosed in sufficient detail.

- Not all revenues and expenses are shown on the income statement; many of the items shown are not disclosed in sufficient detail.

- Revenues are recognized at the moment of production instead of the moment of sales, which departs from the IVth Directive but is basically in accordance with the DSOPA, as far as the produce is concerned that is not sold by year end.

- All farm production is recorded as revenue and valued at year-end market prices. This includes the production which has been sold. Thus sales are valued at year-end market prices instead of actual sales prices.

- Not all revenues and expenses are determined on an accrual basis.

- Holding gains due to changes in the market price of assets are included in revenues and not disclosed separately, instead of being directly credited to a separate item of owners' equity. 
Adapting FADN to GAAP should technically not be very complicated, while it appears that the quality of its data would improve considerably. The question whether, once adapted, FADN could become a European standard, is more difficult to answer. The IVth Directive is silent on most specific issues addressed by FADN; if there is no contradiction between the two, in many cases this is because the Directive is simply not specific enough. The most important conflicts and potential contributions to an improvement of FADN come from the DSOPA therefore. This paper has detected only few contradictions between the DSOPA and the IVth Directive, due to the fact that the latter allows for a wide range of accounting practices. However, there are likely to be many more contradictions between the DSOPA and the interpretations of the IVth Directive in the different EU member states. 
Figure 1; Structure of FADN balance sheets

Fixed assets:

Land and permanent crops

Buildings

Machinery

Breeding livestock

\section{Current assets:}

Non-breeding livestock

Stock agricultural products

Other circ. capital
Net worth

Change in net worth

Long- and medium-term loans

Short-term loans 
Figure 2; Structure of FADN Income Statements

Total Output (by type of production)

+ Subsidies on production and costs

- Intermediate consumptions:

a) Specific costs:

seeds and plants

fertilizers

crop protection

other crop specific costs

feed grazing livestock

feed pigs \& poultry

other livestock specific costs

b) Overheads:

machinery $\&$ building costs

energy

contract work

other direct inputs

- Taxes and VAT balance

= Gross Farm Income

- Depreciation

$=$ Farm Net Value Added

+ Investment grants and subsidies

- External factors:

wages paid

rent paid

interest paid

= Family Farm Income 


\section{References}

Alonso, R. and Serrano, A. (1991) Los Costes en los Procesos de Producción Agraria. Madrid: Mundi-Prensa.

Allen, R. (1994) "Farm potential: high tech leads the average farmer's know-how", Texas Banking, 88 (11): 26.

American Institute of Certified Public Accountants (1996) Audits of Agricultural Producers and Agricultural Cooperatives. New York: AICPA.

André, F. (1987) "Vers un renouveau de la formation économique des agriculteurs?", Économie Rurale, 177: 53-56.

Argilés, J.M. (1998) "Accounting information and the prediction of farm viability", Economics Working Paper 277, Barcelona: Universitat Pompeu Fabra.

Bronstien, B.F. (1995) American Banker, "Group seeking to bring more farmers into line on financial reporting", 27 november 1995: 8.

Bublot, G. (1990-1991) Economie et Gestion de l'Exploitation Agricole Volumes I et II. Lovain: Université Catholique de Louvain, Faculté des Sciences Agronomiques.

Canadian Institute of Chartered Accountants (1986) Comptabilité et Information Financière des Producteurs Agricoles. Toronto: CICA.

Cairns, D. (1997) “The future shape of harmonization: a reply”, European Accounting Review, 6(2): 305-348.

CEC (1988) Red de Información Contable Agrícola. Recopilación de: Reglamentos, Disposiciones de Aplicación, Informaciones. Fascículo III: La Ficha de Explotación. Luxembourg: Office for Official Publications of the European Communities.

CEC (1990) Red de Información Contable Agrícola. Vademécum de Metodología. Luxembourg: Office for Official Publications of the European Communities.

CEC (1991) The Calculation of Economic Indicators Making Use of RICA (FADN) Accountancy Data. Luxembourg: Office for Official Publications of the European Communities.

Crane, L.M. and Leatham, D.J. (1995) 'External equity financing in agriculture via profit and loss sharing contracts: a proposed financial innovation”, Agribusiness, 11 (3): 223-233. 
Dedman, S. (1996) "FADN/RICA and the requirements of financial institutions", in Beers, G., Poppe, K.J. and Pruis, H.C. (eds) Pacioli 2 Accounting and Managing Innovation. The Hague: Agricultural Research Institute LEI-DLO 534, pp.151157.

Domínguez, D. (1981) Cuestiones Especiales Relativas a La Administración y Contabilidad de las Empresas Agrícola-Ganaderas. Madrid: Técnica Bellisco.

Flower, J. (1997) "The future shape of harmonization: the EU versus the IASC versus the SEC", European Accounting Review, 6(2): 281-303.

Flower, J. (1998) "The future shape of harmonization: a reply", European Accounting Review, 7(2): 331-333.

Kroll, J.C. (1987) "Le nouveau plan comptable: les occasions perdues”, Économie Rurale, 180: 20-25.

Launay, R., Beaufrere, J.P. and Debroise, G. (1967) L'entreprise Agricole Analyse, Diagnostic, Prévision. Paris: Librairie Armand Colin.

Lewis, A.E. and Jones, W.D. (1980) "Current cost accounting and farming businesses", Journal of Agricultural Economics, 31: 45-53.

Luening, R.A. (1989) "Farm records can improve profitability", in United States Department of Agriculture, (eds) Farm Management: How to Achieve your Farm Business Goals. US. Washington: Government Printing Office, pp. 103-112.

Pérez, J.A. (1993) "La problemática contable del inmovilizado en las empresas ganaderas", Técnica Contable, 538: 625-636.

Poppe, K.J. (1991) "Information needs and accounting in agriculture", Agricultural Economics Research Institute LEI, 444: 1-51.

Poppe, K.J. and Beers, G. (1996) "On innovation management in Farm Accountancy Data Networks", Agricultural Economics Research Institute LEI, 535: 1-37.

Poppe, K.J. and Breembroek, J.A. (1992) "The assessment of a farm's financial situation with a report writer", Tijdschrift voor Sociaalwetenschappelijk onderzoek, 7(1): 49-70.

Sabaté, P. and Enciso, J.P. (1997) "La valoración de inmovilizados en las empresas agrarias. El caso de las plantaciones", Técnica Contable, 579: 177-184.

Sturgess, I. (1994) “Ce qu'apporte la théorie économique a la mesure et l'interpretation des revenus agricoles", Économie Rurale, 220-221: 11-15.

\footnotetext{
${ }^{1}$ FADN is also known as RICA, its acronym in French.

${ }^{2}$ See paragraph 49 of the Draft Statement of Principle on Agriculture.

${ }^{3}$ Contradictorily, family farm work is included in the valuation of of self- constructed fixed assets.
} 